\title{
HUBUNGAN BERAT BADAN LAHIR RENDAH DAN STATUS IMUNISASI TERHADAP KEJADIAN ISPA PADA BALITA DI WILAYAH KERJA PUSKESMAS TANJUNG BARU OGAN KOMERING ULU
}

\author{
Arda Suryadinata,SKM.,M.Kes \\ Program Studi Kesehatan Masyarakat STIKES AI-Ma'Arif Baturaja \\ Email: arda.suryadinata@gmail.com
}

\begin{abstract}
ABSTRAK
Pendahuluan: Pada usia balita seseorang lebih sering terkena penyakit dibandingkan orang dewasa. Hal ini disebabkan sistem pertahanan tubuh pada balita terhadap penyakit infeksi masih dalam tahap perkembangan dan mudah untuk terkena penyakit dan salah satunya adalah Infeksi Saluran Pernapasan Akut (ISPA) yang merupakan penyakit menular melalui udara yang sering terjadi pada anak dan menjadi salah satu penyebab kematian tersering pada anak di dunia. Salah satu faktor yang dapat menyebabkan terjadinya ISPA pada balita ialah berat badan lahir rendah dan status imunisasi. Berdasarkan data wilayah kerja puskesmas Tanjung Baru pada periode Januari-Desember 2018 menyebutkan bahwa sebanyak 150 balita yang menderita ISPA. Tujuan penelitian: untuk mengetahui hubungan Berat Badan Lahir Rendah dan Status imunisasi lengkap dengan kejadian ISPA di Wilayah Kerja UPTD Puskesmas Tanjung Baru Ogan Komering Ulu. Metode Penelitian: yaitu analitik dengan pendekatan cross sectional dengan populasi adalah ibu di UPTD Puskesmas Tanjung Baru Kabupaten OKU yang berjumlah 53 orang, analisa data dengan uji statistik Chi-Square, dengan derajat kepercayaan 95\%. Didapatkan Ada hubungan yang bermakna antara berat badan lahir rendah dengan kejadian ISPA dengan $p$ value 0,011 < 0,050 . Serta ada hubungan yang bermakna antara Status Imunisasi dengan Kejadian ISPA dengan $p$ value $0,016<0,05$.
\end{abstract}

Kata Kunci: ISPA, BBLR, Status Imunisasi

\section{ABSTRACT}

At the age of a toddler a person is more often affected by the disease than an adult. This is due to the body's defense system in infants against infectious diseases that are still in the developmental stages and are easy to contract the disease and one of them is Acute Respiratory Infection (ARI) which is an infectious disease through the air that often occurs in children and is one of the most common causes of death in children. child in the world. One of the factors that can cause ARI in infants is low birth weight and immunization status. Based on data from the Tanjung Baru puskesmas in the January-December 2018 period, 150150 toddlers suffer from ARI. This study aims to determine the relationship between low birth weight and complete immunization status with the incidence of $A R I$ in the working area of the UPTD Puskesmas Tanjung Baru, East Baturaja Subdistrict, Ogan Komering Ulu Regency in 2019. The method used is analytic with cross sectional approach and the population is mothers with children under five. and have KMS in UPTD Puskesmas Tanjung Baru OKU Regency, totaling 53 people. Which was analyzed by Chi-Square statistical test, with 95\% confidence level. There was a significant relationship between low birth weight with the incidence of $A R I$ with $p$ value $0.011<0.050$. And there is a significant relationship between Immunization Status and the incidence of $A R I$ with $p$ value $0.016<0.05$.

Keywords: ARI, LBW, Immunization Status 


\section{PENDAHULUAN}

Infeksi Saluran Pernapasan Akut (ISPA) merupakan penyakit menular udara yang sering terjadi pada anak dan menjadi salah satu penyebab kematian tersering pada anak di dunia. Kasus ISPA di negara berkembang terbanyak terjadi di India (43 juta), China (21 juta), Pakistan (10 juta), dan Bangladesh, Indonesia, serta Nigeria masing-masing enam juta episode (Kementerian Kesehatan RI, 2012).

World Health Organization (WHO) memperkirakan insiden Infeksi Saluran Pernafasan Akut (ISPA) di Negara berkembang dengan angka kematian balita di atas 40 per 1000 kelahiran hidup adalah $15 \% 20 \%$ pertahun pada golongan usia balita. Menurut WHO \pm 13 juta anak balita di dunia meninggal setiap tahun dan sebagian besar kematian tersebut terdapat di Negara berkembang, dimana pneumonia merupakan salah satu penyebab utama kematian pada kelompok bayi dengan membunuh \pm 4 juta anak balita setiap tahun. Di Indonesia, ISPA selalu menempati urutan pertama penyebab kematian pada kelompok bayi dan balita. Selain itu ISPA juga sering berada pada daftar 10 penyakit terbanyak di rumah sakit. Survei mortalitas yang dilakukan oleh Subdit ISPA tahun 2005 menempatkan ISPA/Pneumonia sebagai penyebab kematian bayi terbesar di Indonesia dengan persentase $22,30 \%$ dari seluruh kematian balita (Imelda, 2017)

$$
\text { Menurut data Riset Dasar }
$$
Kesehatan (2013) Periode prevalensi ISPA di Indonesia berdasarkan diagnosis tenaga kesehatan dan keluhan penduduk prevalensi ISPA sebesar $25 \%$. Jumlah episode ISPA pada balita di Indonesia diperkirakan 3-6 kali per tahun, itu artinya balita mengalami batuk pilek sebanyak 3 sampai 6 kali dalam setahun.

Usia balita lebih sering terkena penyakit dibandingkan orang dewasa. Hal ini disebabkan sistem pertahanan tubuh pada balita terhadap penyakit infeksi masih dalam tahap perkembangan. Salah satu penyakit infeksi yang paling sering diderita oleh balita adalah Infeksi Saluran Pernafasan Akut (ISPA). Infeksi ini mengenai saluran pernafasan yang merupakan organ yang sangat peka sehingga kuman penyakit mudah berkembang biak. Apalagi daya tahan tubuh balita belum kuat ( Syafarilla, 2011).

ISPA dapat menyebabkan kematian terjadi jika penyakit telah mencapai derajat ISPA yang berat, karena infeksi telah mencapai paru-paru atau disebut sebagai pneumonia. Pneumonia merupakan penyakit infeksi penyebab kematian utama, terutama pada balita. Kondisi ISPA ringan dengan batuk pilek biasa sering diabaikan, namun apabila daya tahan tubuh anak lemah penyakit tersebut cepat menjalar ke paru-paru. Kondisi penyakit tersebut bila tidak mendapatkan pengobatan serta perawatan yang baik dapat menyebabkan kematian (Supriatin, 2013).

Balita yang kondisinya saat bayi mengalami BBLR, tidak memperoleh ASI Eksklusif hingga usia 6 bulan dan tidak mendapatkan imunisasi dasar lengkap, balita memiliki status gizi kurang, dan lingkungan rumah yang belum memenuhi syarat rumah sehat dapat mempengaruhi kondisi kesehatan balita yaitu balita menjadi lebih mudah terserang penyakit infeksi seperti, infeksi saluran pernafasan akut (ISPA), diare, pneumonia, dan penyakit infeksi lainnya (lestari, 2017).

Menurut Hending Blum dalam Notoatmodjo (2003) kejadian penyakit dapat dipengaruhi oleh pengetahuan, lingkungan, status imunisasi, ASI eksklusif, dan berat badan lahir. Sementara itu Pio (dkk) (2005) menjelaskan bahwa salah satu faktor resiko terjadinya penyakit ISPA adalah status gizi dan berat badan lahir karena 
ISPA merupakan penyakit infeksi pada balita yang di sebabkan oleh beberapa faktor yang kompleks.

Bayi yang lahir dengan berat badan lahir rendah (BBLR) memiliki risiko lebih tinggi mengalami kematian anak pada umur dini. Penelitian sebelumnya oleh Fibrila (2015), menyimpulkan ada hubungan antara usia anak dan berat badan lahir dengan kejadian ISPA.

Berdasarkan data hasil laporan penyakit ISPA di Dinas Kesehatan Kabupaten Ogan Komering Ulu tahun 2009 berjumlah 10019 (31,88\%) kasus, tahun 2010 berjumlah 9195 (29,25\%) kasus dan pada tahun 2011 berjumlah 6334 (20,15\%) kasus. (Dinkes OKU, 2012).

Berdasarkan data yang diperoleh dari hasil cakupan bulanan P2 ISPA dinas kesehatan Kabupaten Ogan Komering Ulu periode Januari-Desember 2018 di 12 puskesmas terdapat populasi balita di OKU sebanyak 32.805 dengan 13210 orang anak yang menderita penyakit ISPA, diantaranya UPTD Puskesmas Tanjung Baru 681 balita.

Berdasarkan data wilayah kerja puskesmas Tanjung Baru pada tahun 2017 periode Januari-Desember menyebutkan bahwa sebanyak 151 balita dengan penderita ISPA. Pada tahun 2018 periode Januari-Desember menyebutkan bahwa sebanyak 150 balita dengan penderita ISPA Pada tahun 2019 periode Januari-Maret terdapat 30 balita dengan Penderita ISPA (Profil Puskesmas Tanjung Baru, 2018).

\section{METODE PENELITIAN}

Penelitian ini menggunakan metode Survey analitik dengan pendekatan Cross Sectional dimana variabel independen dan variabel dependen dikumpulkan bersamasama (Notoatmodjo, 2010). Populasi pada penelitian ini adalah ibu yang memiliki balita dan mempunyai KMS di UPTD Puskesmas Tanjung Baru Kabupaten Ogan Komering Ulu pada tahun 2019, Penentuan Sampel pada penelitian ini secara accidental sampling yaitu berdasarkan sampel yang ditemukan pada saat penelitian yaitu sebanyak 53 responden

Penelitian ini dilakukan di UPTD Puskesmas Tanjung Baru Kabupaten Ogan Komering Ulu tahun 2019. Waktu penelitian dilaksanakan pada bulan AprilJuli 2019. Yang diperoleh dari hasil wawancara langsung terhadap responden dengan menggunakan check list yang dengan kejadian ISPA dan pengamatan terhadap status imunisasi dan BBLR.

HASIL

Tabel.1

Hubungan berat badan lahir rendah dengan Kejadian ISPA

\begin{tabular}{|c|c|c|c|c|c|c|c|c|}
\hline \multirow{3}{*}{ No } & \multirow{3}{*}{$\begin{array}{l}\text { Berat Badan } \\
\text { Lahir Rendah }\end{array}$} & \multicolumn{4}{|c|}{ Kejadian ISPA } & \multirow{2}{*}{\multicolumn{2}{|c|}{ Jumlah }} & \multirow[b]{2}{*}{$p$ value } \\
\hline & & \multicolumn{2}{|c|}{ Ya } & \multicolumn{2}{|c|}{ Tidak } & & & \\
\hline & & $f$ & $\%$ & $f$ & $\%$ & $f$ & $\%$ & \multirow{4}{*}{0,011} \\
\hline 1 & Ya & 16 & 84,2 & 3 & 15,8 & 19 & 100 & \\
\hline 2 & Tidak & 15 & 44,1 & 19 & 55,9 & 34 & 100 & \\
\hline & Jumlah & 31 & 58,5 & 22 & 41,5 & 53 & 100 & \\
\hline
\end{tabular}


Berdasarkan Tabel.1 diketahui bahwa dari 19 responden dengan berat badan lahir rendah mengalami ISPA berjumlah 16 responden $(84,2 \%)$ dan dari 34 responden dengan berat badan lahir tidak rendah mengalami ISPA berjumlah 15 responden
(44,1\%). Dari hasil uji Chi-Square diperoleh $p$ value $=0,011$ hal ini menunjukkan ada hubungan yang bermakna antara berat badan lahir rendah dengan kejadian ISPA

Tabel.2

Hubungan status imunisasi dengan Kejadian ISPA di UPTD Puskesmas Tanjung Baru Kabupaten Ogan Komering Ulu

\begin{tabular}{|c|c|c|c|c|c|c|c|c|}
\hline \multirow{3}{*}{ No } & \multirow{3}{*}{ Status Imunisasi } & \multicolumn{4}{|c|}{ Kejadian ISPA } & \multirow{2}{*}{\multicolumn{2}{|c|}{ Jumlah }} & \multirow{3}{*}{$p$ value } \\
\hline & & \multicolumn{2}{|c|}{ Ya } & \multicolumn{2}{|c|}{ Tidak } & & & \\
\hline & & $\mathbf{F}$ & $\%$ & $f$ & $\%$ & $\mathbf{f}$ & $\%$ & \\
\hline 1 & Tidak Lengkap & 17 & 81,0 & 4 & 19,0 & 21 & 100 & \multirow{3}{*}{0,016} \\
\hline 2 & Lengkap & 14 & 43,8 & 28 & 56,2 & 32 & 100 & \\
\hline & Jumlah & 31 & 58,5 & 22 & 41,5 & 53 & 100 & \\
\hline
\end{tabular}

Berdasarkan Tabel 5.5 diketahui bahwa dari 21 responden yang status imunisasi tidak lengkap mengalami ISPA berjumlah 17 responden $(81,0 \%)$ dan dari 32 responden yang status imunisasi lengkap mengalami ISPA berjumlah 14 responden (43,8\%). Dari hasil uji Chi-Square diperoleh $p$ value $=0,016$ hal ini

\section{PEMBAHASAN}

Dalam penelitian ini variabel berat badan lahir rendah dibagi menjadi 2 kategori yaitu ya (bila berat badan lahir rendah) dan tidak (bila berat badan lahir normal). Berdasarkan analisa bivariat diketahui bahwa dari 19 responden dengan berat badan lahir rendah mengalami ISPA berjumlah 16 responden $(84,2 \%)$ dan dari 34 responden dengan berat badan lahir tidak rendah mengalami ISPA berjumlah 15 responden (44,1\%).

Dari hasil uji Chi-Square diperoleh $p$ value $=0,011$ hal ini menunjukkan ada hubungan yang bermakna antara berat badan lahir rendah dengan kejadian menunjukkan ada hubungan yang bermakna antara status imunisasi dengan kejadian ISPA .

Dengan demikian hipotesis yang menyatakan ada hubungan antara status imunisasi dengan kejadian ISPA terbukti secara statistik.

ISPA. Dengan demikian hipotesis yang menyatakan ada hubungan antara berat badan lahir rendah dengan kejadian ISPA terbukti secara statistik.

Hasil penelitian ini didukung oleh hasil penelitian yang dilakukan (Imelda, 2017) menyebutkan bahwa bayi dengan berat lahir rendah berhubungan dengan kejadian ISPA di Aceh Besar.

Berat badan lahir rendah (BBLR) umumnya lebih berisiko terhadap kematian di banding dengan berat badan lahir yang Normal, ini disebabkan karena zat anti kekebalan dalam tubuh serta paruparu yang belum terbentuk sempurna sehingga menyebabkan bayi dengan 
BBLR sangat rentan terhadap penyakit termasuk ISPA. Menurut molyneux dalam Annisa (2018).

Dalam penelitian ini variabel status imunisasi dibagi menjadi 2 kategori yaitu lengkap (jika balita mendapat kelengkapan imunisasi dasar) dan tidak lengkap (jika balita tidak mendapat kelengkapan imunisasi dasar). Berdasarkan analisa bivariat diketahui bahwa dari 21 responden yang status imunisasi tidak lengkap mengalami ISPA berjumlah 17 responden $(81,0 \%)$ dan dari 32 responden yang status imunisasi lengkap mengalami ISPA berjumlah 14 responden $(43,8 \%)$.

Dari hasil uji Chi-Square diperoleh $p$ value $=0,016$ hal ini menunjukkan ada hubungan yang bermakna antara status imunisasi dengan kejadian ISPA . Dengan demikian hipotesis yang menyatakan ada hubungan antara status imunisasi dengan kejadian ISPA terbukti secara statistik.

Hasil penelitian yang berhubungan dengan status imunisasi menunjukkan bahwa ada kaitan antara penderita ISPA yang mendapatkan imunisasi tidak lengkap dan lengkap, dan bermakna secara statistis. Menurut penelitian yang dilakukan (Imelda, 2017) menyebutkan bahwa ketidak patuhan imunisasi berhubungan dengan peningkatan penderita ISPA.

Imunisasi bermanfaat untuk mencegah beberapa jenis penyakit infeksi seperti, Polio, TBC, difteri, pertusis, tetanus dan hepatitis B. Bahkan imunisasi juga dapat mencegah kematian dari akibat penyakit-penyakit tersebut. Sebagian besar kasus ISPA merupakan penyakit yang dapat dicegah dengan imunisasi, penyakit yang tergolong ISPA yang dapat dicegah dengan imunisasi adalah difteri, dan batuk rejan (Depkes RI, 2011).

Pemberian imunisasi dapat mencegah berbagai jenis penyakit infeksi termasuk ISPA. Untuk mengurangi faktor yang meningkatkan mortalitas ISPA, diupayakan imunisasi lengkap terutama DPT dan Campak. Bayi dan balita yang mempunyai status imunisasi lengkap bila menderita ISPA dapat diharapkan perkembangan penyakitnya tidak akan menjadi berat. Ketidakpatuhan imunisasi berhubungan dengan peningkatan penderita ISPA, hal ini sesuai dengan peneliti lain yang mendapatkan bahwa imunisasi yang lengkap dapat memberikan peranan yang cukup berarti dalam mencegah kejadian ISPA ( Maryunani, 2010 )

Berdasarkan hasil penelitian yang telah dilakukan anak yang status imunisasinya tidak lengkap lebih banyak yang menderita ISPA dari pada anak yang status imunisasinya lengkap, menurut asumsi peneliti hal ini karena kekebalan tubuh anak Balita juga dipengaruhi oleh status imunisasi, oleh karena itu imunisasi sangat penting karena peluang untuk terkena penyakit terutama ISPA lebih kecil dibandingkan dengan anak yang status imunisasinya tidak lengkap.

\section{KESIMPULAN}

Dari hasil penelitian yang telah dilakukan di UPTD Puskesmas Tanjung Baru Kabupaten Ogan Komering Ulu Tahun 2019, dapat disimpulkan bahwa :

1. Ada hubungan yang bermakna antara berat badan lahir rendah dengan Kejadian ISPA di UPTD Puskesmas Tanjung Baru Tahun 2019 dengan uji statistik didapat $p$ value 0,011

2. Ada hubungan yang bermakna antara Status Imunisasi dengan Kejadian ISPA di UPTD Puskesmas Tanjung Baru Tahun 2017 dengan uji statistik didapat $p$ value 0,016 


\section{DAFTAR PUSTAKA}

1. Arikunto, Suharsimi. 2010. Prosedur Penelitian Suatu Pendekatan Praktek. Jakarta : Rineka Cipta

2. Depkes RI. 2012. Profil Kesehatan Indonesia 2012. Jakarta : Depkes RI

3. Ditjen PP dan PL. 2012. Laporan P2 ISPA Seluruh Provinsi. Jakarta : Kemenkes RI

4. Imelda. 2017. Hubungan Berat Badan Lahir Rendah dan Status Imunisasi dengan Kejadian Infeksi Saluran Pernafasan Akut pada Balita di Aceh Besar. Fakultas keperawatan Universitas Syiah Kuala Banda Aceh

5. Kemenkes RI. 2012. Laporan Ditjen PP dan PL. Kemenkes RI. Jakarta : Depkes RI

6. Lestari Novantyas Dwi.2017. Hubungan Antara Kondisi Saat Bayi, Status Gizi, Dan Lingkungan Dengan Kejadian Ispa Faringitis Pada Balita Di Wilayah Kerja Puskesmas Sangkrah Surakarta. Universitas Muhammaddiyah Surakarta.

7. Marimbi, Hanum. 2010. Tumbuh Kembang, Status Gizi dan Imunisasi Dasar pada Balita . Yogyakarta : Nuha Medika

8. Notoatmodjo, Soekidjo. 2010. Metode Penelitian Kesehatan. Jakarta : Rineka Cipta

9. Santoso, Fitriarma. 2011. Faktorfaktor Eksternal Pneumonia pada Balita di Jawa Timur dengan Pendekatan Geographically Weighted Regression. Surabaya : ITSN
10. Suprihatin, Eva. 2013. Hubungan Faktor-faktor dengan Kejadian Penyakit ISPA pada alita di Puskesmas $X$ Kota Bandung Tahun 2013. Bandung : Sekolah Tinggi IImu Keperawatan (STIKep) PPNI Jabar

11. Tim Penyusun UPTD Puskesmas Tanjung Agung: Laporan Program P2 ISPA tahun 2018

12. Widoyono. 2008. Penyakit Tropis: Epidemiologi, Penularan, Pencegahan dan Pemberantasannya. Jakarta : Erlangga

13. Yulius, Oscar. 2010. IT Kreatif : SPSS 18. Yogyakarta : Panser Pustaka 